Pregledni članak UDK 114/115(045) Bošković, R. doi: $10.21464 /$ fi39303 Primljeno: 27. 8. 2019.

\title{
Roko Pešić
}

Nacionalna i sveučilišna knjižnica u Zagrebu, Hrvatske bratske zajednice 4, HR-10000 Zagreb roko.pesic@gmail.com

\section{Osvrt na Boškovićevo razumijevanje prostora $i$ vremena}

\begin{abstract}
Sažetak cije spomenute Boškovićeve misli s konceptima suvremene fizike.

Ključne riječi

Ruđer Josip Bošković, prostor, vrijeme, aktualno, potencijalno
\end{abstract}

U radu je dan kratak osvrt na Boškovićevu misao o dvoslojnosti prostora $i$ vremena, (i) stvarnom (aktualnom) prostoru i vremenu te (ii) matematičkom (potencijalnom) prostoru $i$ vremenu, iz pretežito fizikalnog aspekta. U radu su navedeni primjeri moguće koresponden-

\section{Uvod}

U prostoru i vremenu odvija se cjelokupno postojanje - egzistencija svih živih bića i nežive materije, tj. čitavog svemira. Prostor i vrijeme spadaju u toliko temeljne čovjekove pojmove i zorove, toliko su srasli sa svakodnevnim ljudskim iskustvom da gotovo nikome - osim filozofa i fizičara, pokojeg umjetnika $^{1}$ - uopće ne pada na pamet baviti se njima. Zašto je tomu tako? Duhovit je odgovor na to pitanje dao Albert Einstein kad su ga jednom, pomalo zajedljivo, pitali za njegovo mišljenje o tome zašto je baš on - a ne netko drugi - stvorio teoriju relativnosti. Einstein je ovako obrazložio:

»Čini mi se da je razlog sljedeći: normalno odrastao čovjek uopće ne razmišlja o problemu prostora i vremena. Po njegovom mišljenju on je s tim pitanjima raščistio još u djetinjstvu. Ja sam se, međutim, razvijao tako sporo da su prostor i vrijeme zaokupljali moje misli kad sam već bio odrastao $(\ldots) . \ll^{2}$

U njegovoj specijalnoj teoriji relativnosti prostor su i vrijeme - do tada smatrani za dva odvojena entiteta - spojeni u neraskidivo jedinstveno prostorvrije$m e .{ }^{3}$ Kasnije, kada je specijalnu teoriju relativnosti proširio na opću teori-

1

Jorge Luis Borges, slavni argentinski pisac, napisao je: »Vrijeme je tvar od koje sam stvoren. Vrijeme je rijeka koja me odnosi, ali ja sam ta rijeka; ono je tigar koji me razara, ali ja sam taj tigar; ono je vatra koja me guta, ali ja sam ta vatra.« - Jorge Luis Borges, »A New Refutation of Time«, u: Jorge Luis Borges, Other Inquisitions, prevela Ruth L. C. Simms, University of Texas Press, Austin 1964., str. 171-187, str. 187.
2

Gerald E. Tauber, Einsteinova opća teorija relativnosti, preveo Damir Mikuličić, Globus, Zagreb 1984., str. 7.

3

McGraw-Hill concise encyclopedia of physics, McGraw-Hill Professional, Sjedinjene Američke Države 2005., str. 615. 
ju relativnosti, Einstein je prostorvremenu pridodao još i materiju odnosno gravitaciju. ${ }^{4}$ U njegovoj općoj teoriji relativnosti gravitacija se objašnjava geometrijom prostora, čija se zakrivljenost mijenja u blizini tijela s velikom masom, što je kasnije i eksperimentalno potvrđeno mjerenjem savijanja zrake svjetlosti u gravitacijskom polju Sunca. ${ }^{5}$ Slikovito rečeno, materija je u svemiru poput nekakvih čvoruga i neravnina koje iskrivljuju prostorvrijeme, svemir nije ravan u euklidskom smislu, moramo odbaciti pojmove pravca $\mathrm{i}$ ravnine itd. ${ }^{6}$ (ta »neravnost « opaža se tek preciznim astronomskim mjerenjima golemih svemirskih udaljenosti). To je slikovito izrazio C. Nordmann, jedan od prvih popularizatora teorije relativnosti:

»Vrijeme je bilo u klasičnoj, njutnovskoj fizici poput rijeke što nosi pojave kao i rijeka brodove; pa i onda kad nema brodova rijeka teče nepromijenjenim tokom. A i prostor je kao obala te rijeke neovisan o lađama u prolazu. Po Einsteinu, međutim, kada nema brodova ne teče ni rijeka. A i oblik se obale mijenja pod djelovanjem lađa u prolazu. « ${ }^{7}$

Međutim, usuprot Einsteinu, ljudsko svakodnevno iskustvo i predodžba prostora, dakle, ono što čovjek vidi, jest prostor koji postoji kao obujam koji omogućuje smještaj predmetima, poput beskonačno velike kutije u koju možemo slagati predmete po pravilima euklidske geometrije, ${ }^{8}$ koja je za naše zemaljske udaljenosti sasvim prikladna i dovoljna. 'Vidimo', neovisno od prostora, i vrijeme kao dimenziju događanja i koje, kako nam se čini, teče neovisno o događajima. To svakidašnje ljudsko iskustvo bilo je temelj za višestoljetnu filozofsku misao o prostoru i vremenu, još od antičkih mislilaca, napose Aristotela, ${ }^{9}$ zatim rimskog pjesnika i filozofa Lukrecija Kara, ${ }^{10}$ preko Aurelija Augustina ${ }^{11}$ i Tome Akvinskog ${ }^{12}$ pa do Isaaca Newtona i Immanuela Kanta. ${ }^{13} \mathrm{~S}$ obzirom na to da namjera autora ovog kratkog osvrta nije bila detaljna filozofska elaboracija, već pogled iz fizikalne perspektive na neke aspekte Boškovićeve teorije, ovdje ću istaknuti samo poimanje prostora i vremena kako se pojavljuje kod Newtona, začetnika novovjekovne fizike i neposrednog prethodnika Ruđera Boškovića. Newton je svoje poimanje jasno izrazio u definiciji pojmova tzv. apsolutnog prostora i apsolutnog vremena, odnosno njihovom razlikovanju od pojmova relativnog prostora i relativnog vremena:

»Apsolutno, pravo i matematičko vrijeme, samo od sebe, i od svoje vlastite prirode, teče jednolično, bez odnosa prema ičemu izvanjskom, a naziva se još i trajanje: relativno, prividno i javno vrijeme je nekakva osjetna i izvanjska (...) mjera trajanja pomoću gibanja, koja je u uobičajenom korištenju umjesto pravog vremena (...). Apsolutni prostor, po svojoj vlastitoj prirodi, bez odnosa prema ičemu izvanjskom, ostaje uvijek sličan i nepokretan. Relativni prostor je (...) pokretna dimenzija ili mjera apsolutnog prostora; koju naša osjetila određuju njezinim položajem prema tijelima; i koja se obično poima kao nepokretni prostor; takva je dimenzija podzemnog, zračnog i nebeskog prostora, određenih njihovim položajem u odnosu na zemlju. « ${ }^{14}$

Po mišljenju Newtona, apsolutni i relativni prostor, premda imaju isti oblik i veličinu, ipak se razlikuju, na način kao što se razlikuju referentni sustavi ${ }^{15} \mathrm{u}$ fizici: ako se Zemlja giba, tada se - sa stajališta nekog opažača koji se nalazi dovoljno daleko u svemiru, u mirujućem sustavu zvijezda stajačica - s njom giba i prostor koji zauzima njena atmosfera. Naime, taj se pokretni prostor $\mathrm{u}$ jednom trenutku nalazi u jednom dijelu apsolutnog i nepokretnog prostora kroz koji prolazi zrak, a u drugom se trenutku nalazi u drugom dijelu tog istog prostora. ${ }^{16}$ Suprotno apsolutnom, pokretni je prostor koji atmosfera zauzima relativan - ovisi o referentnom sustavu (sustavu opažača). Newtonov apsolutni prostor jest mirujući inercijski referentni koordinatni sustav Euklidove geometrije $^{17}$ u kojem vrijede (Newtonovi) zakoni gibanja, napose zakon tromosti (inercije). ${ }^{18}$ Primjer je takvog sustava spomenuti sustav zvijezda stajačica. U takvom sustavu nema dodatnih sila koje djeluju u tzv. neinercijskim 
(ubrzanim) sustavima, npr. u dizalu koje se uspinje ili automobilu koji vozi u kružnom zavoju, a koje moramo uzeti u obzir kod opažanja i mjerenja.

\section{Boškovićeva misao o konačnosti prostora i vremena}

Među misliocima i filozofima prirode koji su dali značajni doprinos shvaćanju prostora i vremena ističe se i veliki hrvatski znanstvenik i isusovački filozof Ruđer Josip Bošković. Njegova misao o prostoru i vremenu nastavlja

Sila gravitacije jedna je od četiriju temeljnih međudjelovanja u prirodi. Po Newtonovu općem zakonu gravitacije bilo koja dva tijela masa $m_{1}$ i $m_{2}$ uzajamno se privlače silom koja je razmjerna masama, a obrnuto razmjerna kvadratu njihove udaljenosti. Usp. Vjera Lopac, Leksikon fizike, Śkolska knjiga, Zagreb 2009., str. 88

5

G. E. Tauber, Einsteinova opća teorija relativnosti, str. 116-118.

6

Usp. ibid., str. 10, 106-114.

7

Ibid., str. 11, 89, 100-101.

8

Npr., peti Euklidov postulat glasi: Ako jedan pravac presječen dvama pravcima čini $\mathrm{s}$ iste strane dva unutrašnja kuta čiji je zbroj manji od dva prava kuta, ta dva pravca, beskonačno produžena, sjeći će se s one strane s koje su ti kutovi manji od dva prava. Usp. Srđan Lelas, Tihomir Vukelja, Filozofija znanosti: s izborom tekstova, Školska knjiga, Zagreb 1996., str. 11.

Aristotel je definirao vrijeme ovako: »Vrijeme je broj gibanja prema onomu prije i prema onomu poslije.« Drugim riječima, vrijeme je povezano s promjenom odnosno gibanjem, $\mathrm{tj}$. ono služi kao mjera gibanja tijela od sadašnjeg trenutka, bilo prema prošlosti, bilo prema budućnosti. Bez gibanja govor o vremenu nema smisla. Još jedna njegova misao o vremenu je: »Tempus est ens rationis.« Aristotel je vrijeme (kao i prostor) smatrao »umskim bićem « utemeljenim u stvarnosti. Vidi: Stanko Anić-Milić, Kozmologija - filozofija prirode, Makarska, OFM 1977., str. 106.

10

»Tako ni vrijeme o sebi ne postoji, nego od stvari / Oduzmu ćutila naša, u prošlosti štono se zbilo / Što se upravo zbiva, ubuduće što će se zbiti. / Nitko ne može vrijeme o sebi da ćutilom shvati, / Ako ne omjeri stvari mirovanja, njihove kretnje.« - Tit Lukrecije Kar, $O$ prirodi, preveo Marko Tepeš, Matica hrvatska, Zagreb 1952., str. 80, stih 459-464.

11

»Što je dakle vrijeme? Tko bi to mogao i samo mišlju shvatiti pa da to onda riječju ne izrazi? A je li nam išta običnije i poznatije što u govoru spominjemo nego vrijeme? (...) Ako me nitko ne pita, znam; ako želim nekome pitanje protumačiti, ne znam." Augustin prošlost, sadašnjost i budućnost shvaća kao tri vremenske dimenzije, koje se sastaju u ljudskoj duši - prošlost kao sjećanje, sadašnjost kao opažanje, a budućnost kao očekivanje. Usp. Ivan Čagalj, »Vrijeme u filozofiji Aurelija Augustina«, Crkva u svijetu 13 (1978) 1, str. 52-58, str. 53.

12

U svojoj raspravi »De aeternitate mundi «, Toma Akvinski filozofski obrazlaže da svijet, premda stvoren od Boga kao prauzroka svega stvorenog, ne mora nužno imati vremenski početak. Usp. Toma Akvinski, »O vječnosti svijeta«, preveo Tomo Vereš, Obnovljeni život 29 (1974) 4, str. 367-380.

13

Za razliku od Newtona, Kant ne smatra da prostor i vrijeme postoje neovisno od nas, već da su forme našeg zora (forme a priori) pomoću kojih mi sređujemo svoje iskustvo, odnosno načini na koje mi opažamo stvarnost. Usp. Immanuel Kant, Kritika čistoga uma, preveo Nikola Popović, Beogradski izdavačko-grafički zavod, Beograd 1990., str. 53-62.

14

Isaac Newton, Mathematical principles of natural philosophy, preveo Andrew Motte, Encyclopaedia Britannica, Chicago 1996. str. 8.

15

Referentni je sustav koordinatni sustav u kojem se nalazi opažač koji opisuje gibanje. Usp. V. Lopac, Leksikon fizike, str. 201.

16

I. Newton, Mathematical principles of natural philosophy, str. 9.

17

Usp. Stipe Kutleša, Prirodno-filozofijski pojmovi Ruđera Boškovića, Hrvatsko filozofsko društvo, Zagreb 1994., str. 263.

18

V. Lopac, Leksikon fizike, str. 101. 
se na Newtonovu i Leibnizovu, ${ }^{19}$ ali se i razlikuje od njih. Naime, Newton je uveo dva prostora: stvarni (empirijski), koji je dan relativnim položajima tijela, i apsolutni, koji je nosilac inercije i mehaničkih zakona. ${ }^{20}$ Taj apsolutni prostor nazvao je još pravim ili matematičkim prostorom. Za Leibniza je ideja apsolutnog prostora apsurdna jer po njegovu mišljenju prostor sam za se, bez monada, ne postoji. Bošković je od Newtona preuzeo razliku stvarnog i matematičkog prostora, a od Leibniza ideju monada, bez kojih ne postoje ni prostor ni vrijeme. Leibniz ne razlikuje stvarni i matematički prostor, no odnos tih dvaju prostora bit će srž Boškovićeve teorije. ${ }^{21}$ Po mišljenju Boškovića, prostor su i vrijeme modusi (načini) egzistiranja stvari; izvan i mimo stvari govor o prostoru i vremenu nema smisao: ${ }^{22}$

»Prije svega, meni se čini posve jasnim da i oni koji prihvaćaju pojam prostora kao nešto apsolutno što je po svojoj stvarnoj naravi kontinuirano, vječno i neizmjerno i oni koji s leibnizovcima i kartezijancima postavljaju sam prostor u red koji imaju među sobom stvari što postoje, mimo svog postojanja, moraju prihvatiti nekakav način koji nije čisto imaginaran, već stvarni način postojanja, po kojem se stvari nalaze tamo gdje jesu i koji postoji tada kada su one tamo, a nestaje onda kada ih nema tamo gdje su bile. $\ll^{23}$

Bošković je uveo bitnu novost, naime matematički prostor shvaća kao potencijalni u razrađenom peripatetičkom (aristotelovskom) smislu. ${ }^{24}$ Taj je smisao izražen u izvornoj grčkoj riječi $\delta v ́ v \alpha \mu \iota \varsigma$ koju Aristotel rabi, u značenju sila, moć, možnost (lat. potentia): $:^{25}$

»Postoji nešto koje je samo ostvarenošću, nešto koje je samo možnošću, nešto koje je i možnošću i ostvarenošću (...) jasno je da je gibanje ostvarenost možnoga kao možnoga. Tako je jasno kako je ona gibanje, i kako se tada ponaša da se štogod giba kada biva ta ostvarenost, a ne ni prije ni poslije. $\ll^{26}$

Na tragu Aristotela, Boškovićevi su nazori o prostoru i vremenu najuže povezani s njegovom dinamičkom atomistikom i jedinstvenim zakonom sila koji vlada među njegovim »nedjeljivim i neprotežnim točkama«, kao što se vidi u uvodnom odlomku njegova teksta u Supplementa no 1. De spatio, ac tempore:

»Ja nikako ne prihvaćam da bi protežnost materije bila posve kontinuirana, već držim da se sastoji od posve nedjeljivih i neprotežnih točaka međusobno odijeljenih nekim razmakom, usto povezanih nekim silama koje su čas privlačne, čas odbojne, a ovise o njihovim međusobnim udaljenostima. Ovdje moramo vidjeti što je po mojoj teoriji prostor, a što vrijeme, u kojem ih smislu možemo nazvati kontinuiranim i djeljivim u beskonačnost, vječnim, neizmjernim, nepokretnim i nužnim, iako nijedno od njih, (...) nema svoju stvarnu narav koja bi posjedovala ta svojstva. $\ll^{27}$

Boškovićevi pogledi na (bes)konačnost prostora odnosno vremena proizlaze iz shvaćanja beskonačnosti bliskog Aristotelovu: ${ }^{28}$ beskonačno postoji samo u mogućnosti, tj. kao nešto potencijalno, a ne aktualno. ${ }^{29}$ Aristotel to izražava ovako:

»I u cijelosti, ako je nemoguće da biva neograničeno ${ }^{30}$ mjesto, jer je svako tijelo u mjestu, nemoguće je i da bude neograničeno tijelo (...). Iz tih je dokaza bjelodano kako djelatnošću ne postoji neograničeno tijelo (...). Preostaje dakle da neograničeno biva možnošću. Samo ne treba to 'bivajuće možnošću' shvatiti kao: ako je ovo možno biti kip, to će i biti kip, pa će tako i neograničeno biti djelatnošću, nego budući se bitak kazuje mnogovrsno, kao 'dan je' ili 'natjecanje je', zbog toga što uvijek nastaje štogod drugo i drugo, te tako i neograničeno (jer i u tih stvari se biva i možnošću i djelatnošću. Naime, Olimpijska svečanost biva i zbog toga što može nastati natjecanje i zbog toga što nastaje) (...). Uz to, bitak se ne kazuje mnogovrsno, tako te neograničeno ne treba uzeti kao štogod 'ovo', kakav je čovjek ${ }^{31}$ ili kuća, nego kao što se kaže dan ili natjecanje, kojima bitak nije nastao kao neko bivstvo, nego je uvijek u nastanku ili nestanku, neograničen, ali uvijek drukčiji i drukčiji. ${ }^{32}$

Aristotel ovdje kaže da beskonačnost biva na isti način na koji bivaju dan ili Olimpijske igre, koji nisu ozbiljeni (aktualizirani) u svojoj cjelokupnosti u 
svakom času vremena kao što pojedina stvar jest, nego njihovi dijelovi dolaze u egzistenciju sukcesivno jedan za drugim. Dan počinje zorom pa zatim slijede ostali njegovi dijelovi, redom: jutro, prijepodne, poslijepodne i večer. Beskonačno, po mišljenju Aristotela, ne opisuje pojedinačne stvari, kao što su ljudi ili kuće, ni u smislu aktualnog ni potencijalnog, nego samo sljedove (nizove) pojedinačnih stvari ili događaja određenih - da se izrazimo matematički - u svakom članu niza, ali uvijek različitih stvari. ${ }^{33}$ Drugim riječima, nemoguće je da ono što egzistira u stvarnosti i što je u sebi određeno postoji kao beskonačno malo i beskonačno veliko. ${ }^{34} \mathrm{U}$ svom glavnom djelu Bošković kaže:

»To će dobro doći da se svaki koegzistentni kontinuum eliminira iz prirode, zbog kojeg su se, da ga protumače, filozofi dosad i te kako naznojili, i to gotovo uzaludno. Stoga niti će se moći u

19

Usp. Tomislav Petković, Tomislav Petković, ml., »Boškovićevo djelo u filozofiji prirode u razvoju moderne fizike čestica. O 300-toj obljetnici Boškovićevog rođenja«, Filozofska istraživanja 32 (2012) 2, str. 343-360, str. 346-347, 352.

20

I. Newton, Mathematical principles of natural philosophy, str. 9, 14.

21

Usp. Ivan Supek, Ruđer Bošković - vizionar u prijelomima filozofije, znanosti i društva, Zagreb 1989., str. 65-66.

22

S. Kutleša, Prirodno-filozofijski pojmovi Ruđera Boškovića, str. 264.

23

»Inprimis illud mihi videtur evidens, tam eos, qui spatium admittunt absolutum, natura sua reali, continuum, aeternum, immensum, tam eos, qui cum Leibnitianis, \& Cartesianis ponunt spatium ipsum in ordine, quem habent inter se res quae existunt, praeter ipsas res, quae existunt, debere admittere modum aliquem non pure imaginarium, sed realem existendi, per quem ibi sint, ubi sunt, \& qui existat tum, cum ibi sunt, pereat cum ibi esse desierint, ubi erant.« - Ruđer Josip Bošković, Teorija prirodne filozofije, preveo Jakov Stipišić, Sveučilišna naklada Liber, Zagreb 1974., str. 264.

24

Aristotel je dao svoje tumačenje promjenljivih, pokretnih bića (ens mobile) sastavljenih, po njegovu mišljenju, od dva momenta: mogućeg (potencijalnog), ako je (biće) u mogućnosti da postane nešto, i stvarnog (aktualnog), ako je (biće) stvarno, aktualno formirano. To vrijedi za sva promjenljiva bića, od atoma do čitavog svemira. Usp. S. Anić-Milić, Kozmologija, str. 8.

25

U Ladanovu prijevodu (vidi bilj. 26), iako Ladan u tumaču dozvoljava i mogućnost (lat. possibilitas), u značenju vjerojatnost, eventualnost, ipak preporuča razlikovanje tih dvaju izraza.
26

Aristotel, Fizika, preveo Tomislav Ladan, Hrvatska sveučilišna naklada, Zagreb 1992. knj. III, str. 43, 46.

27

»Ego materiae extensionem prorsus continuam non admitto, sed eam constituo punctis prorsus indivisibilibus, et inextensis a se invicem disjunctis aliquo intervallo, et connexis per vires quasdam jam attractivas, jam repulsivas pendentes a mutuis ipsorum distantiis. Videndum hic, quid mihi sit in hac sententia spatium, ac tempus, quomodo utrumque dici possit continuum, divisibile in infinitum, aeternum, immensum, immobile, necessarium, licet neutrum, ....suam habeat naturam realem ejusmodi proprietatibus praeditam.« - R. J. Bošković, Teorija prirodne filozofije, Dopuna I., str. 264.

28

Usp. Jaakko Hintikka, »Aristotelian infinity «, The Philosophical Review 75 (1966) 2, str. 197-218, str. 198.

29

Ivica Martinović, »The concept of the infinity mysteria in Bošković's geometrical investigations «, Prilozi za istraživanje hrvatske filozofske baštine 41 (2015) 1, str. 61-91, str. 89.

30

U Ladanovu tumaču neograničeno u Aristotelovu tekstu znači beskonačno. Usp. Aristotel, Fizika, str. 229.

31

Aristotel ovdje pretpostavlja shvaćanje čovjeka blisko materijalističkom, naime, da je čovjek ograničen i konačan, poput svih ostalih materijalnih stvari.

32

Aristotel, Fizika, str. 58-59.

33

J. Hintikka, »Aristotelian infinity«, str. 199.

34

Stipe Kutleša, »Izvornost prirodnofilozofijskih pojmova kod Ruđera Boškovića«, Prilo- 
beskonačnost izvoditi ikakvo stvarno dijeljenje bića, niti će ostati u zraku pitanje je li broj dijelova stvarno razdijeljenih ili koji se mogu dijeliti konačan ili beskonačan, niti će više biti drugih bezbrojnih pitanja koja su dosad mučila filozofe u vezi sa složenosti kontinuuma.« 35

Po mišljenju Boškovića, matematički je ili potencijalni prostor kontinuiran, dok njegove točke-atomi čine stvarni prostor koji je diskretan. Na taj je način pomirio filozofsko načelo kontinuiranosti s atomističkom diskontinuiranošću. Među tim točkastim atomima nema praznog prostora, što proizlazi iz temeljnog načela srednjovjekovne aristotelovske fizike, po kojem je prostor kontinuiran i ispunjen pa je bilo kakva praznina nemoguća. No naša je geometrija utemeljena na neprekinutosti. Kako pomiriti tu diskretnost fizičkih točaka i nužnu matematičku kontinuiranost? U potrazi za odgovorom na ovo pitanje, Bošković se, kako je prije spomenuto, priklanja Aristotelovoj dihotomiji aktualno - potencijalno. Aktualni ili stvarni (fizički, empirijski, iskustveni) prostor dan je rasporedom fizičkih točaka, dok je matematički ili imaginarni (apsolutni, virtualni) prostor potencijalni, drugim riječima, on predstavlja mogućnost gibanja, tj. može se aktualizirati u gibanju točaka-atoma. S tim u vezi, Bošković razlaže ideju gibanja koja je neprestano pretvaranje potencijalnih (virtualnih) položaja i vremena u zbiljske. ${ }^{36}$ Ta predodžba podsjeća na kvantnu teoriju polja koja gibanje elementarnih čestica povezuje s tvorbom ili poništenjem parova virtualnih čestica ${ }^{37} \mathrm{i}$ antičestica.

Analogiju dihotomije aktualno-potencijalno imamo i u kvantnim procesima. Za razliku od klasične fizike u kojoj imamo jednoznačnu vezu uzroka (sile) A koji djeluje na tijelo i predvidljive posljedice B (kao ishoda tog djelovanja) koju možemo, barem u načelu, točno odrediti iz diferencijalne jednadžbe gibanja (naravno, u okviru neizbježne mjerne nesigurnosti, tj. statističke pogreške mjerenja), u kvantnoj fizici to ne možemo pa čak niti načelno zbog fenomena neodređenosti kojeg je prvi utvrdio i eksplicirao Werner Karl Heisenberg (Heisenbergove relacije neodređenosti). ${ }^{38}$ Ono što možemo jest izračunati kolike su pojedine vjerojatnosti da će se kvantni sustav nakon djelovanja uzroka A nalaziti u nekom od više mogućih stanja $\mathrm{B}_{1}, \mathrm{~B}_{2}, \mathrm{~B}_{3}, \ldots$. Tek u trenutku opažanja/mjerenja kvantni sustav (npr. atom, elektron...) od tih mogućih stanja »odabire« jedno stanje u kojem se može opaziti. Drugim riječima, to stanje od potencijalnog (mogućeg) prelazi u aktualno (stvarno).

Primjer koji to dobro ilustrira jest paradoks koji je smislio utemeljitelj valne mehanike Erwin Schrödinger u poznatom misaonom eksperimentu, po njemu nazvanom »Schrödingerova mačka «. ${ }^{39}$ Pretpostavimo da je u čeličnu kutiju s Geigerovim brojačem, bočicom u kojoj se nalazi otrov, čekićem i radioaktivnom tvari smještena jedna mačka. Kad se radioaktivna tvar raspadne, brojač registrira promjenu i automatski aktivira čekić, koji razbije bočicu i potom otrov ubije mačku. Raspad radioaktivne tvari slučajni je proces i ne možemo predvidjeti kada će se dogoditi. Fizičari kažu da svaki pojedini atom radioaktivne tvari u ovom slučaju postoji u superpoziciji dvaju mogućih stanja - u isto je vrijeme raspadnut ili neraspadnut. Sve dok ne otvori kutiju, opažač ne zna živa li je mačka ili mrtva jer joj sudbina ovisi o tome raspao li se neki atom ili nije. Dakle, dok se ne promatra, mačka bi, po mišljenju Schrödingera, bila istovremeno živa i mrtva. Međutim, kad otvori kutiju i pogleda mačku, opažač će odmah vidjeti koje se stanje aktualiziralo. Drugim riječima, superpozicija dvaju mogućih (potencijalnih) stanja mačke aktualizirat će se u jedno od njih - »živa mačka« ili »mrtva mačka«, ali nikako ne i jedno i drugo istovremeno, kao što je to bilo prije otvaranja kutije. Paradoks u ovom misaonom pokusu proizlazi iz toga što mačka ne može »glumiti« atom jer se makroskopska tijela pokoravaju Newtonovim zakonima, a atomi ne. Oni su, 
naime, opisani valnom funkcijom koja je kombinacija svih mogućih valnih funkcija koje postoje u danoj situaciji - u ovoj dviju. Valna funkcija kaže da za svako moguće (potencijalno) stanje postoji određena vjerojatnost da će se atom naći baš u tom stanju, ali bez opažanja ne možemo reći koje će od tih stanja postati aktualno.

Pogledajmo kako Bošković opisuje način postojanja stvari (tj. tijela) u stvarnom prostoru i stvarnom vremenu:

»Prema tomu nužno se mora prihvatiti stanoviti stvarni način postojanja po kojem se stvar nalazi tamo gdje jest i tada kada jest. Bilo da taj način nazovemo stvar ili modus stvari ili nešto što nije ništa, on mora biti izvan naše imaginacije i stvar ga može mijenjati, tako da ima čas jedan, čas drugi takav način postojanja. $\ll^{40}$

To je u potpunom skladu s našim uobičajenim pojmom stvarnosti, odnosno načinom na koji stvarnost opisuje klasična fizika: mirovanje odnosno gibanje tijela u prostoru i vremenu opisano je položajem u kojem se tijelo nalazi u određenom trenutku vremena. Bošković, međutim, taj opis proteže i na atome koje on smatra fizičkim točkama:

»Svaka točka ima jedan stvaran način postojanja, po kojem se nalazi tamo gdje jest, i drugi po kojem se nalazi u vrijeme kada postoji. Po mom su mišljenju ti stvarni načini stvarno vrijeme i prostor. Mogućnost tih načina, koju mi neodređeno spoznajemo, jest po mom mišljenju prostorni vakuum i, da tako kažem, vremenski vakuum ili pak imaginarni prostor i imaginarno vrijeme. Ti stvarni načini pojedinačno nastaju i pojedinačno propadaju. I po mom su mišljenju posve nedjeljivi, neprotežni i nepokretni, a i nepromjenljivi u svom redu. Oni, a i mjesta i vremena njihova i njihovih točaka kojima pripadaju, jesu stvarni. Oni pružaju temelj stvarnog odnosa udaljenosti, tj. lokalne među dvjema točkama ili vremenske između dvaju događaja. ${ }^{41}$

zi za istraživanje hrvatske filozofske baštine 19 (1993) 1-2, str. 75-114, str. 78.

35

»Sed et illud commodum accidet, quod ita omne continuum coexistens eliminabitur e natura, in quo explicando usque adeo desudarunt, et fere incassum, philosophi nec idcirco divisio ulla realis entis in infinitum produci poterit, nec haerebitur, ubi quaeratur, an numerus partium actu distinctarum, et separabilium, sit finitus, an infinitus; nec alia eiusmodi sane innumera, quae in continui compositione usque adeo negotium facessunt philosophis, jam habebuntur.« - R. J. Bošković, Teorija prirodne filozofije, str. 41 .

36

Usp. Stipe Kutleša, »Doprinos Ruđera Boškovića filozofiji prirode i znanosti«, Radovi Zavoda za povijesne znanosti HAZU u Zadru 37 (1995), str. 567-581.

37

Virtualne čestice su čestice koje postoje u vrlo kratkom vremenskom intervalu; njihovo stvaranje omogućeno je narušavanjem zakona očuvanja energije u istom intervalu u okvirima Heisenbergovih relacija neodređenosti. Tako npr. nuklearna se sila, koja djeluje među nukleonima, prenosi emisijom i apsorpcijom virtualnih piona. Usp. Valerie H. Pitt, The Penguin Dictionary of Physics, Penguin Group, London 1977., str. 404.

\section{8}

Eyvind H. Wichmann, Kvantna fizika: udžbenik fizike Sveučilišta u Berkeleyu, sv. 4, prijevod N. Zovko, Tehnička knjiga, Zagreb 1988., str. 125-131.

39

Usp. Werner Heisenberg, Fizika i filozofija, preveo Stipe Kutleša, KruZak, Zagreb 1997., str. 176

40

»Necessario igitur admittendus est realis aliquis existendi modus, per quem res est ibi, ubi est, et tum, cum est. Sive is modus dicatur res, sive modus rei, sive aliquid, sive nonnihil; is extra nostram imaginationem esse debet et res ipsum mutare potest, habens jam alium ejusmodi existendi modum, jam alium. - Philosophiae recentioris a Benedicto Stay...versibus traditae libri $X, \ldots$ cum adnotationibus et supplementis P. Rogerii Josephi Boscovich, Tomus I, Romae 1755., str. 341.

41

»Quodlibet punctum habet modum realem existendi, per quem est ibi, ubi est, et alium, per quem est tum, cum est. Hi reales existendi modi sunt mihi reale tempus et spatium: horum possibilitas a nobis indefinite cognita est mihi spatium vacuum, et tempus itidem ut ita dicam vacuum, sive etiam spatium imaginarium, et tempus imaginarium. Modi illi reales singuli et oriuntur, ac pereunt et indivisibiles 
Odavde se može zaključiti da svaki dio prostora ima svoje (»lokalne«) udaljenosti među česticama i svoja vremena među događajima:

»Kao što je to s mjerenjem vremena, tako je za moju teoriju u pogledu mjerenja prostora nemoguće prenositi određenu duljinu, kao tamo trajanje, sa svog mjesta na drugo mjesto da bismo mogli usporediti dvije stvari trećom. $\ll^{42}$

Bošković se ovdje približio pojmovima relativnih prostornih dimenzija lokalnog vremena u teoriji relativnosti u kojoj svaki sustav ima svoje vlastito vrijeme i prostor i u kojoj su svi sustavi - prostori kao i vremena - ravnopravni. Bošković, međutim, ne precizira kako se vrijeme i prostor mijenjaju - produžuju li se ili skraćuju udaljenosti i vremenski intervali, tako da se njegova teorija u tome razlikuje od relativističke kontrakcije dužina i dilatacije vremena. Rezimirajmo: ovakav je Boškovićev pristup opisu ponašanja njegovih točaka-atoma dopunjen i profinjen njutnovski pristup ${ }^{43}$ koji se temelji na tri prostorne i jednoj vremenskoj koordinati jer je u njemu implicite sadržana pretpostavka da atomi postoje na način analogan načinu postojanja makroskopskih tijela. ${ }^{44}$ To je sasvim razumljivo s obzirom na to da nije imao na raspolaganju složeni matematički formalizam teorijske fizike (valne funkcije, matrice i dr.) i nije mu bio poznat dualizam val-čestica, uveden tek početkom 20. stoljeća utemeljenjem kvantne teorije, da bi se na suvisao način moglo objasniti neobično ponašanje atoma i subatomskih čestica koje se ne podvrgavaju Newtonovim zakonima gibanja kao makroskopska tijela. Kao što je već spomenuto, prostorne i vremenske koordinate ne mogu zahvatiti svu subatomsku stvarnost, već je za egzaktni opis te stvarnosti potreban složeniji matematički formalizam.

Treba istaknuti da Bošković poima stvarno vrijeme i prostor kao stvarne moduse postojanja koji »pojedinačno nastaju i pojedinačno propadaju« kao konačni i ograničeni. Spomenimo ovdje i Boškovićevu zamisao prostora kakav bi, umjesto tri, imao četiri dimenzije. Do te zamisli došao je analizom rezultantne sile koja se javlja u slučaju kada na neku točku djeluje proizvoljan broj drugih točaka:

»Stoga bi svakoj točki na bilo kojem mjestu odgovarala njezina rezultantna sila, a bila bi potrebna i neka četvrta strana ili dimenzija pored dužine, širine i dubine da bi se mogle povući iz svih točaka prostora dužine razmjerne onim silama (...). Ali ono što ne postiže geometrija postiže neka zamišljena četvrta dimenzija (...). Stoga bi se tražile tri takve dimenzije u prostoru koji je četverodimenzionalan ili koji ima četvrtu kvalitetu $(\ldots) . \ll^{45}$

Uz sve postojeće razlike i premda je nije do kraja razradio, ova Boškovićeva zamisao jasno pokazuje bliskost njegovih shvaćanja o prostoru i vremenu sa shvaćanjima teorije relativnosti. ${ }^{46}$

Nakon što je utvrdio stvarni modus postojanja, stvarno vrijeme i prostor, Bošković počinje konstruirati prethodno opisani potencijalni ili matematički prostor, koji još naziva imaginarnim. Po njegovu mišljenju, taj prostor nalazi se u našem umu pa u mislima mi možemo svaki razmak razdijeliti u još manji, a taj manji razmak u još manji i tako u beskonačnost. Za beskonačnu djeljivost Bošković je našao mnoštvo dokaza, premda, ističe da se svi geometrijski dokazi koji potvrđuju beskonačnu djeljivost odnose na neprekinuti protežni prostor, a ne na tvar. ${ }^{47}$ Matematički prostor homogen je i kontinuiran. Bošković zaključuje da njegove točke mogu zauzeti bilo koje mjesto između njihovih razmaka: 
načni prostor bio je istodobno i vječan i nužan, ali ne kao nešto što [stvarno] postoji, nego samo kao nešto što može postojati, i koji mi neodređeno zamišljamo $(\ldots) . \ll^{48}$

Osim stvarnog postojanja čestica-točaka u stvarnom vremenu i prostoru, Bošković uvodi matematički ili potencijalni prostor i vrijeme što bivaju aktualizirani u opažanom gibanju. Naime, kao što je već spomenuto, ${ }^{49}$ Boškovićevi su nazori o prostoru i vremenu najuže povezani s njegovom teorijom jedinstvene sile koja djeluje među njegovim »nedjeljivim i neprotežnim točkama«. Ta sila određuje njihove aktualne položaje i razmake tih točaka i gibanja koja opažamo i mjerimo. Nadalje, Bošković definira imaginarni prostor kao trodimenzionalni kontinuum geometrijskih ili imaginarnih točaka, zamišlja ga samo kao mogući (potencijalni) način postojanja tvarnih točaka (položaja) koje tvore realan prostor. Isto tako, imaginarno vrijeme predstavlja jednodimenzionalni i neprekinuti kontinuum imaginarnih trenutaka te je samo mogući način postojanja tvarnih točaka (trenutaka) realnog vremena. Dakle, od svih mogućih položaja koje tvarne točke odnosno tijela mogu zauzeti u nekom vremenskom trenutku aktualizirat će se samo oni položaji i gibanja podvrgnuta Boškovićevoj jedinstvenoj privlačno-odbojnoj sili - odbojnoj na među-atomskim udaljenostima, a privlačnoj na velikim, svemirskim udaljenostima.

prorsus mihi sunt, ac inextensi, et immobiles, ac in suo ordine immutabiles. Ii et sua ipsorum loca sunt realia, ac tempora, et punctorum, ad quae pertinent. Fundamentum praebent realis relationis distantiae, sive localis inter duo puncta, sive temporariae inter duos eventus. « - Philosophiae recentioris a Benedicto Stay...versibus traditae libri $X$,... cum adnotationibus et supplementis P. Rogerii Josephi Boscovich, Tomus I, Supplementum ad librum primum $p$. VI., »De spatio, ac tempore«, Romae 1755., str. 341-342. Vidi i: R Bošković, Teorija prirodne filozofije, Dopuna I., br. 4 , str. 265

\section{2}

»In mensura locali aeque in mea sententia, ac in mensura temporaria impossibile est certam longitudinem, ut certam durationem e sua sede abducere in alterius sedem, ut binorum comparatio habeatur per tertium. «-R. J. Bošković, Teorija prirodne filozofije, str. 275.

43

Boškovićeva krivulja sila uz privlačni asimptotski luk na velikim udaljenostima od izvora sile, koji je nalik Newtonovoj privlačnoj gravitacijskoj sili, na malim udaljenostima ima i odbojni asimptotski luk koji predstavlja neproničnost (neprobojnost) čestica; to je izvorna Boškovićeva ideja. Vidi: R. J. Bošković, Teorija prirodne filozofije, str. 264.

44

Boškovićeve točke-atomi odgovarali bi kvarkovima, osnovnim sastavnim djelićima tvari, nedjeljivim česticama od kojih se sastoje subatomske čestice. Slobodni kvarkovi dosada nisu opaženi, već postoje isključivo u vezanom stanju - po dva ili tri kvarka zajedno formiraju složenije čestice, kao što su proton, neutron itd.
45

»Hinc pro quovis puncto loci ubicunque assumpto sua responderet vis composita, et quarta aliqua plaga, seu dimensio, praeter longum, latum et profundum, requireretur ad ducendas ex omnibus punctis spatii rectas iis viribus proportionales (...) Sed quod Geometria non assequitur, assequeretur quarta alia dimensio mente concepta. (...) adeoque tria loca eiusmodi ad spatium, quarta aliqua dimensione, vel qualitate affectum requirerentur...«-R. J. Bošković, Teorija prirodne filozofije, str. 91, br. 209 (bilj. o).

46

Usp. S. Kutleša, Prirodno-filozofijski pojmovi Ruđera Boškovića, str. 312.

47

Usp. Rogerii Joseph Boscovich, De continuitatis lege et eius consectariis pertinentibus ad prima materiae elementa eorumque vires, Romae 1754

48

»Hinc vero dum concipimus possibilia haec loci puncta, spatii infinitatem, et continuitatem habemus, cum divisibilitate in infinitum...spatium huiusmodi imaginarium contiuum, infinitum, simul etiam aeternum fuit, et necessarium, sed non est aliquid existens, sed aliquid tantummodo potens existere, et a nobis indefinite conceptum $(\ldots) . \ll-$ R. J. Boscovich, »De spatio, ac tempore «, Romae 1755., str. 343 .

49

Bilješka br. 27. 
Ta dihotomija aktualnog (stvarnog) i potencijalnog (mogućeg) pojavila se u kvantnoj fizici. Kao što se u kvantnoj fizici govori o virtualnim ${ }^{50}$ česticama ili virtualnim atomskim stanjima, tako bi se, po mišljenju Boškovića, moralo govoriti o virtualnom prostoru i vremenu za razliku od aktualno zauzetih položaja i trenutaka. Poznata je Heisenbergova usporedba atomskog sustava s virtualnim orkestrom u kojem pojedini svirač koji je tiho »gudio « odjednom 'iskače iz podruma' sa svojim zvukom. ${ }^{51}$ Možemo reći da je Bošković u nekom smislu prethodnik suvremenih ideja o funkcioniranju mikrosvijeta.

\section{Zaključak}

Bošković je poimanjem prostora i vremena te svojom dinamičkom atomistikom bio daleko ispred svoga vremena. Nije pretjerano reći da su njegove ideje o povezanosti prostora i vremena s materijom, doduše neizravno, prethodile Einsteinovoj (općoj, odnosno specijalnoj) teoriji relativnosti. U njoj je, naime, uveden novi fizikalni pojam prostorvrijeme u kojem je mjesto (položaj) tijela opisano pomoću četiri ravnopravne prostorno-vremenske koordinate koje korespondiraju s Boškovićeva dva ravnopravna, stvarna modusa postojanja točaka - prostornim i vremenskim. Osim toga, Bošković je daleko prije Lorentza ${ }^{52}$ zastupao promjenu dimenzije tijela prilikom prenošenja $\mathrm{s}$ jednog mjesta na drugo. Međutim, kako nije imao nikakve eksperimentalne podloge, to je ostala samo teorijska pretpostavka, čija je važnost utoliko još i veća. ${ }^{53} \mathrm{Uz}$ to, Bošković se osvrnuo i na problem pravocrtnosti, ustvrdivši da je pravac isto tako jednostavan kao i svaka druga krivulja unatoč tome što se nama ne čini tako. Iz svojstava tih krivulja, kako on navodi, ${ }^{54}$ mogli bismo sačiniti elemente neke posve druge geometrije. Time je on anticipirao neeuklidsku geometriju, koju su matematičari otkrili mnogo kasnije i koja je primijenjena u općoj teoriji relativnosti.

Nadalje, razlikovanje aktualnog i potencijalnog prostora ima, iako tek kao slutnju, korespondenciju sa suvremenim kvantnomehaničkim tumačenjem aktualizacije virtualnih (potencijalnih) procesa u času mjerenja. Naime, za razliku od situacije u klasičnoj fizici, gdje npr. količina gibanja (umnožak mase i brzine tijela) za dane vrijednosti mase i brzine generira samo jedan broj, kvantnomehanički operator (matrica) koji, pojednostavljeno rečeno, opisuje djelovanje neke »sile« na atomski sustav, veliki skup brojeva. Ti brojevi predstavljaju moguća (potencijalna) stanja koje atomski sustav može zauzeti prilikom mjerenja, od kojih se aktualizira (filozofskim rječnikom rečeno: ozbiljuje) samo jedno stanje. ${ }^{55}$

Osim toga, to razlikovanje (aktualnog i potencijalnog) u skladu je s našom intuitivnom percepcijom svijeta kao nečega protežnoga u prostoru, ali što se razvija s vremenom. Intuitivno pridajemo posebno značenje sadašnjem trenutku koji vidimo - da se izrazimo rječnikom fizike - kao krestu »vremenskog vala « koji neprestano pretvara potenciju (budućnost) u akt (sadašnjost) i ostavlja ga u prošlosti. Tu intuitivnu percepciju ne možemo napustiti kao nešto sasvim subjektivno jer ona ima objektivno utemeljenje u nizu bioloških, geoloških i astronomskih procesa.

Također, potencijalni, imaginarni ili matematički prostor sa svojim svojstvima kontinuiranosti i neprekidnosti daje podlogu osnovnim pojmovima suvremene matematičke analize. Boškovićevo poimanje i objašnjenje načela kontinuiteta $^{56}$ formulirano je kao zahtjev da se promjena ili prijelaz s jednog stanja na drugo odvija preko svih međustanja, odnosno on znači odsustvo skoka pri bilo kakvoj fizičkoj promjeni. Sažeti izraz toga načela sadržan je u pozna- 
toj izreci »Natura non facit saltus «. ${ }^{57}$ Međutim, Bošković to načelo ovdje ne uzima kao svojstvo stvarnog nego kao svojstvo spomenutog matematičkog prostora odnosno vremena, a na tome se načelu formulira pojam neprekidnosti funkcije u matematičkoj analizi. Naime, Bošković je istraživanjem transformacija geometrijskih mjesta nastojao potkrijepiti svoje shvaćanje i pojam neprekinutosti. Po njegovu mišljenju, neprekinuto se mijenja i tangenta na krivulju što, izraženo jezikom moderne matematičke analize, znači da su prve derivacije funkcije neprekinute odnosno Boškovićeva geometrijska krivulja glatka je krivulja. ${ }^{58}$

Konačno, Boškovićeva teza o konačnosti aktualnog prostora i vremena upućuje na njihovu kontingenciju odnosno početak pa je u nekom smislu prethodnica kozmološke teorije velikog praska (Big Bang) koja tumači početak i evoluciju svemira. Spomenutom je tezom Bošković na tragu Augustinova shvaćanja da vrijeme uz psihološko-subjektivni doživljaj ima i objektivnu osnovu, naime, da je vrijeme počelo zajedno s gibanjem stvorenih stvari, za razliku od Kanta i Heideggera, ali i nekih suvremenih znanstvenika koji su vrijeme relativizirali, odnosno sveli samo na psihičku kategoriju ili formu opažanja. ${ }^{59}$

Kao zaključak može se sažeti da Bošković stoji na poziciji konačnosti stvarnog prostora i stvarnog vremena te promjenljivosti i propadljivosti cjelokupne materije, ${ }^{60}$ a beskonačnosti i nužnosti matematičkog ili imaginarnog pro-

50

Virtualan (lat. virtus - snaga, vrlina) - jak, sposoban za djelovanje, ali skriven, koji se ne pojavljuje ali se može pojaviti u budućnosti; potencijalan, eventualan. Usp. Bratoljub Klaić, Rječnik stranih riječi, Nakladni zavod Matice hrvatske, Zagreb 1979.

51

Ova metafora aludira na prije spomenuto ponašanje atoma koji od više mogućih (virtualnih) stanja u trenutku mjerenja aktualizira (ozbiljuje) samo jedno. Usp. I. Supek, Ruđer Bošković - vizionar u prijelomima filozofije, znanosti $i$ društva, str. 86.

52

Hendrik Antoon Lorentz nizozemski je fizičar koji je otkrio relativističke izraze za transformaciju relativističkih koordinata čestice pri velikim brzinama, tzv. Lorentzove transformacije.

53

Usp. Stipe Kutleša, Filozofija Ruđera Boškovića, Kruzak, Zagreb 2012., str. 71.

54

»... aliud mentium genus, quod cuiuspiam ex ipsis proprietatem aliquam aeque evidenter intueretur, ac nos intuemur congruentiam rectarum, illas maxime simplices esse crederet curvas lineas, ex illa earum proprietate longe alterius geometriae sibi elementa conficeret (...).«-R. J. Bošković, Teorija prirodne filozofije, str. 52, br. 116.

55

Usp. Henry Margenau, »Metafizički elementi u fizici«, preveo Emil Kušan, ČEMU: časopis studenata filozofije 11 (2013), str. 137-163.
56

Usp. Marija Knežević, »Boškovićeva eksplikacija načela kontinuiteta «, Acta Iadertina 10 (2013) 1, str. 37-48.

57

Izreka koja označava evolucijski princip, tj. da se u prirodi sve odvija kroz postupno i neprekinuto kretanje i razvoj, nasuprot dijalektičkom (skokovitu) principu. Tu misao izrekao je već Aristotel, a kasnije su ju prihvatili Jan Amos Komensky, Meister Eckhart, Johann Wolfgang von Goethe, Carl von Linné i dr. 58

R. J. Boscovich, De continuitatis lege et eius consectariis pertinentibus ad prima materiae elementa eorumque vires, str. 93.

59

I. Čagalj, »Vrijeme u filozofiji Aurelija Augustina $\ll$, str. 56, 58.

60

S fizikalne točke gledišta, stabilnost materije zasniva se na stabilnosti atomskih jezgara, koje se sastoje od protona i neutrona. U nestabilnim jezgrama obje čestice su podložne beta raspadu, kod kojega se proton raspada u neutron, odnosno neutron u proton, uz zračenje elektrona odnosno pozitrona, i (anti) neutrina. Međutim, kada su izvan jezgre, svi dosadašnji eksperimenti pokazuju da je slobodni proton, za razliku od slobodnog neutrona, stabilan (što ne znači da se ubuduće neće pokazati suprotno). Dakle, ovo pitanje ostaje još uvijek otvoreno, iako na temelju dosadašnjih saznanja nije pogrešno zaključiti da je raspad protona moguć. 
stora odnosno vremena. Beskonačnost u našem stvarnom prostorvremenu ne postoji kao aktualnost, već samo kao mogućnost, koja nadilazi granice naše spoznaje ili, kako piše Bošković, koju mi »sasvim neodređeno poimamo«. ${ }^{61}$

\title{
Roko Pešić
}

\section{Brief Examination of Boscovich's Understanding of Space and Time}

\begin{abstract}
From a more physicalistic point of view the paper gives a brief overview of Boscovich's thought about the bilayer of space and time, (i) real (actual) space and time, and (ii) mathematical (potential) space and time, without going into philosophical analysis in detail. The paper provides examples of possible correspondence between Boscovich's thought and physicalist concepts in modern physics.
\end{abstract}

\section{Key words}

Roger Joseph Boscovich, space, time, actual, potential 